\title{
Microbiomes of the initial soils of mining areas of Yakutsk City (Eastern Siberia, Russia)
}

\author{
Alexey Zverev ${ }^{1}$, Alexey Petrov ${ }^{1}$, Anastasia Kimeklis ${ }^{1}$, Arina Kichko ${ }^{1}$, \\ Evgeny Andronov ${ }^{1}$, Alexey Petrov ${ }^{2}$, Evgeny Abakumov ${ }^{1 *}$ \\ ${ }^{1}$ Saint-Petersburg State University, Saint-Peterburg, Russia \\ ${ }^{2}$ Institute of Applied Ecology of the North, Yakusts, Russia
}

\begin{abstract}
The microbiome of initial soils formed at the heaps and bottoms of surface sediment quarries in the surroundings of Yakutsk City (Eastern Siberia, Russia) has been characterized for the first time. In the initial Entisols, we detected Alphaproteobacteria (represented mainly by the family Rizobiales), Gammaproteobacteria, Actinobacteria, Acidobacteria, Bacteroidetes (mostly Chitinophagales), Deltaproteobacteria, and Chloroflexi. The lower soil horizons had a more homogenous species diversity taxonomy that was dominated by Gammaproteobacteria. The morphologically different horizons did not differ microbiologically. This is caused by the limited soil development and relatively slow rate of revegetation of the spoil banks and heaps of the quarries under the severe climatic conditions of the Eastern part of Russian Arctic zone. Based on our findings, we propose that the soil microbiomes in such recently abandoned quarries are characterized by low diversity, which is a characteristic feature of the polar soils surrounding Yakutsk. Data obtained can be used for elaboration of reclamation strategies with taking into account the information about key microbial drivers of soil processes.
\end{abstract}

Key words: Yakutsk, soils, microbiome, metagenomic, mine, quarries

DOI: $10.5817 / \mathrm{CPR} 2020-1-7$

\section{Introduction}

The soil microbiome plays an important role in the development of the soil profile and the implementation of key soil-biochemical processes (Frouz et al. 2016). This is especially important for the initial stages of soil regeneration following strong anthropogenic impacts ( $\mathrm{Li}$ et al. 2015, Harantová et al. 2017). Until recently, efforts to understand microbial participation in soil processes have been limited because soil microbiology was mainly based on cultivation methods (Andronov et al. 2011). At the same time, cultivated organisms represent only about $5 \%$ of the total soil microbiome. However, new tools and possibilities for the investigation of soil metag-

Received September 11, 2019, accepted April 20, 2020.

*Corresponding author: E. Abakumov<abakumov@mail.ru, e.abakumov@spbu.ru>

Acknowledgements: This work was supported by the Russian Scientific Foundation, project № 1716-01030 "Soil biota dynamics in chronoseries of post-technogenic landscapes: analyses of soilecological effectiveness of ecosystems restoration". Authors are grateful to MSc. I. Alekseev and MSc. E. Popova for their assistance in field works. 
enomic diversity are now driving intensive progress in soil microbiology (Andronov et al. 2011).

Classical microbiological research has largely not devoted much attention to the ignored northern soils of cold regions. Only a few microbiological works can be can be reported in this respect. Some studies were addressed to Yamal and Taymyr peninsulas and few islands of the Northern Ocean (Kirtsideli and Vlasov 2016, Kirtsideli et al. 2014, 2016; Danilova et al. 2012, Vlasov et al. 2014). These were mainly focused on the investigation of the microbiota of polar settlements. Data on the soil microbial communities that develop on post-mining heaps in the Siberian part of Russia are limited by few works and this is caused by numerous logistical difficulties (Vlasov et al. 2014). It is important to understand the structure of microbial communities on post-mine heaps. This information is useful for efforts to promote soil formation, which could be used to accelerate land reclamation processes and restoration of natural/seminatural plant communities. Only a few studies have investigated the soil microbiomes of former mines in the Arctic (e. g. White et al. 2015). It has been shown that Proteobacteria are the most dominant family of bacteria in former asbestos mines of Northern Canada. Metagenomic investigation of po-

\section{Material and Methods}

\section{The study sites}

We analyzed soils of various types of surface quarries used for road construction (Table 1). The sampling sites P1 and P2 were two soil sections, which were quarries of sand and gravel deposits. These soils were similar to a great extent, and were in the initial stages of formation. P3 was the bottom of the open pit, deposits and soil formation were not noted. The control soils lar urban environments (Kirtsideli et al. $2017 a, b)$ showed that the diversity of fungi is increased in urban environments relative to natural environments. The same results were shown for Antarctic environments affected by human in comparisons with native ones (Kirtsideli et al. 2017). At the same time, the microbiome of anthropogenically-affected soil (Technosol, Turbic, Transportic) of the territory of Bellingshausen station (King George Island, Antarctica) had a lower diversity of microorganisms than natural soils of the same area (Abakumov et al. 2017, Pershina et al. 2018a). In addition, it is possible that global warming will lead to the changes in the soil microbial community in the Arctic. These changes may comprise an increase in the dominance of the Actinobacteria and significant reductions in the Gemmatimonadaceae and Proteobacteria in the soil organic layer (Deslippe et al. 2012).

Here we aimed to characterize the metagenomic composition of the soil microbiome of young developing soils of the postmining landscape of Central Yakutia. This work had two principal objectives: (1) to investigate the soil restoration process in cases of abundant and reclamation practices; and (2) to characterize the soil microbial community using the $\alpha$ - and $\beta$-diversity indexes.

(Y1 and Y2) were morphologically similar, i.e. gray-humus Psammozems (Arenosols) formed on the surface of dumps from sand and gravel production. There was an evidence of an accumulation of organic matter in the upper horizons, passing sharply and directly into the horizon of the parent rock. 


\begin{tabular}{|c|c|c|c|c|}
\hline $\begin{array}{l}\text { Sample } \\
\text { code }\end{array}$ & $\begin{array}{l}\text { Type of } \\
\text { environment }\end{array}$ & Coordinates & $\begin{array}{l}\text { Soil name, vegetation } \\
\text { cover }\end{array}$ & $\begin{array}{l}\text { Names of } \\
\text { horizons, } \\
\text { depth, cm }\end{array}$ \\
\hline $\mathrm{P} 1$ & $\begin{array}{l}\text { The bottom of } \\
\text { the Kildyamsky } \\
\text { sand quarry }\end{array}$ & $\begin{array}{l}\text { N } 62^{\circ} 19,0717^{\prime} \\
\text { E } 129^{\circ} 47,3377^{\prime}\end{array}$ & $\begin{array}{l}\text { Embryozem organo- } \\
\text { accumulative, forbs } \\
\text { with a predominance } \\
\text { of fireweed } \\
\text { (Chamaenerion } \\
\text { angustifolium) } 90- \\
100 \% \text { projective cover }\end{array}$ & $\begin{array}{l}\text { P1.AO 0-5 } \\
\text { R1.C 5-15 }\end{array}$ \\
\hline $\mathrm{P} 2$ & $\begin{array}{l}\text { The bottom of } \\
\text { the Kildyamsky } \\
\text { sand quarry }\end{array}$ & $\begin{array}{l}\text { N } 62^{\circ} 19,0953^{\prime} \\
\text { E } 129^{\circ} 47,3289^{\prime}\end{array}$ & $\begin{array}{l}\text { Initial embryozem, } \\
\text { single specimens of } \\
\text { ruderal vegetation } \\
\text { (Chamaenerion } \\
\text { angustifolium, } \\
\text { Tussilago farfara) }\end{array}$ & P2.C - 0-27 \\
\hline P3 & $\begin{array}{l}\text { The bottom of } \\
\text { the Kildyamsky } \\
\text { sand quarry }\end{array}$ & 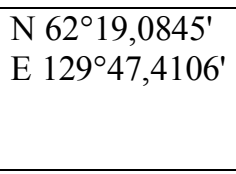 & $\begin{array}{l}\text { Organo-accumulative } \\
\text { embryozem, young } \\
\text { pine forest (Pinus } \\
\text { sylvestris). }\end{array}$ & P1.AO 0-3 \\
\hline $\mathrm{Y} 1$ & $\begin{array}{l}\text { Old Tabaga } \\
\text { settlement, self- } \\
\text { growing quarry } \\
\text { for sand and } \\
\text { gravel deposits }\end{array}$ & $\begin{array}{l}\text { N 6150,16112' } \\
\text { E } 129^{\circ} 31,3011^{\prime}\end{array}$ & $\begin{array}{l}\text { Gray-humus } \\
\text { psammozem (Betula } \\
\text { alba, Salix caprea, } \\
\text { Pinis sylvestris. ) forbs, } \\
32 \% \text { projective cover. }\end{array}$ & $\begin{array}{l}\text { Y1.AY 0-5 } \\
\text { Y1.C 5-30 }\end{array}$ \\
\hline $\mathrm{Y} 2$ & $\begin{array}{l}\text { A quarry for the } \\
\text { extraction of } \\
\text { packed sand } \\
\text { deposits in the } \\
\text { area of Yakutsk } \\
\text { poultry farm }\end{array}$ & $\begin{array}{l}\text { N 61 }{ }^{\circ} 59,4031^{\prime} \\
\text { E } 129^{\circ} 35,5803^{\prime}\end{array}$ & $\begin{array}{l}\text { Gray-humus } \\
\text { psammozem, single } \\
\text { plant (Phragmites } \\
\text { australis) overgrowing, } \\
55 \% \text { projective cover. }\end{array}$ & $\begin{array}{l}\text { Y2.AY 0-3 } \\
\text { Y2.C 3-30 }\end{array}$ \\
\hline
\end{tabular}

Table 1. Characterics of sampling plots.

\section{Sampling and routine chemical analyses}

Samples from each point were taken in triplicate for molecular analysis, as well as one sample for agrochemical studies. The selected samples were transported at $4^{\circ} \mathrm{C}$ and stored at $-20^{\circ} \mathrm{C}$. Fig. 1 brings several images of the sampling sites and surrounding vegetation. The organic carbon content was estimated using a C-H-N analyzer Euro 3028-HT [1]. The $\mathrm{pH}$ values of the aqueous extract were determined at a ratio of 1:2.5. The Kirsanov method with the
CINAO modification ([4]-GOST R 546502011) was used to determine the mobile phosphorus and potassium compounds. The exchangeable forms ammonium rate was determined according to the CINAO method ([2]-GOST 26489-85), and the nitrates were determined by the ionometric method ([3]-GOST 26951-86). The rates of basal respiration (BR) were measured according to the method of Ananeva (Ananeva et al. 2011). 
A. ZVEREV et al.
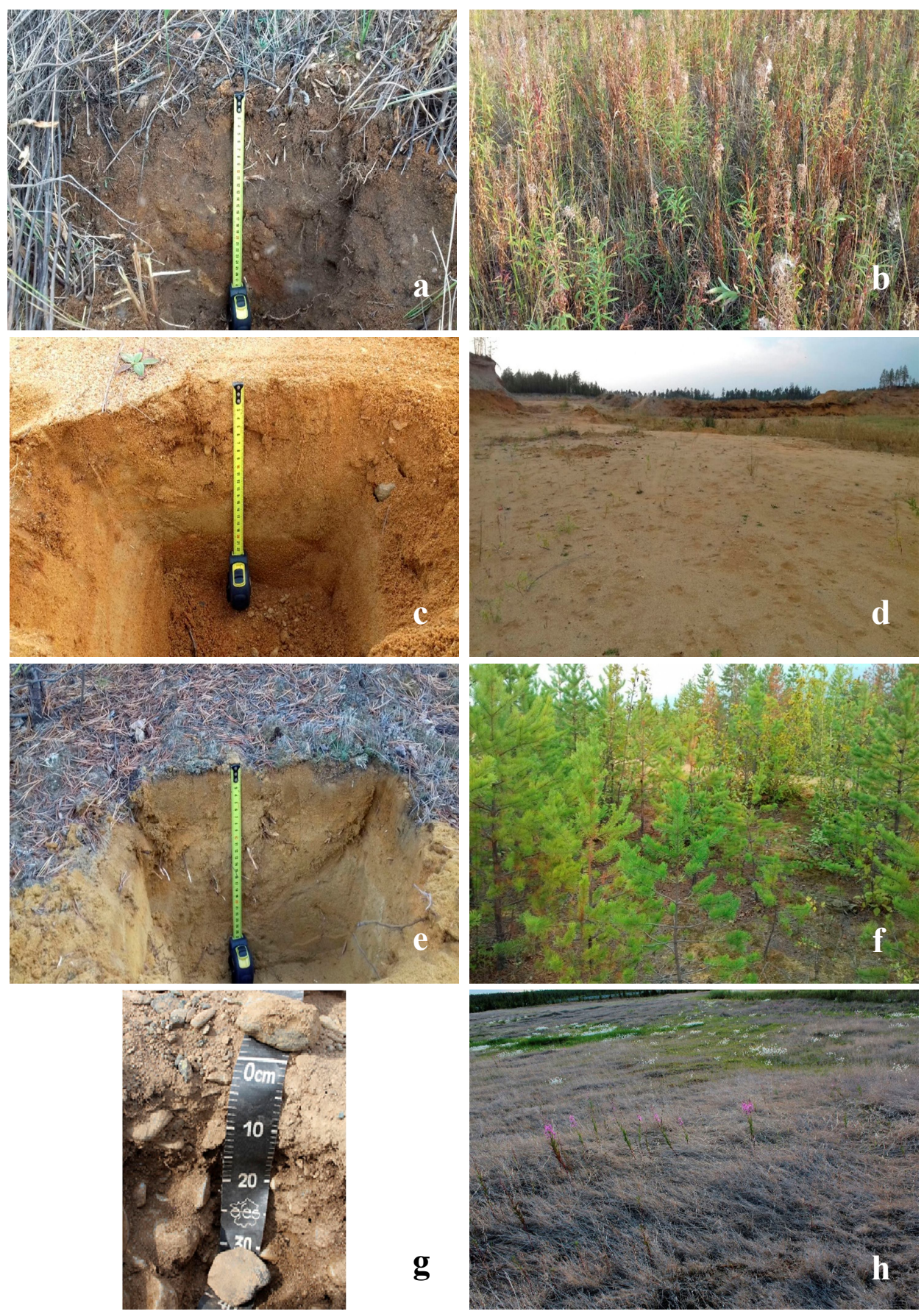

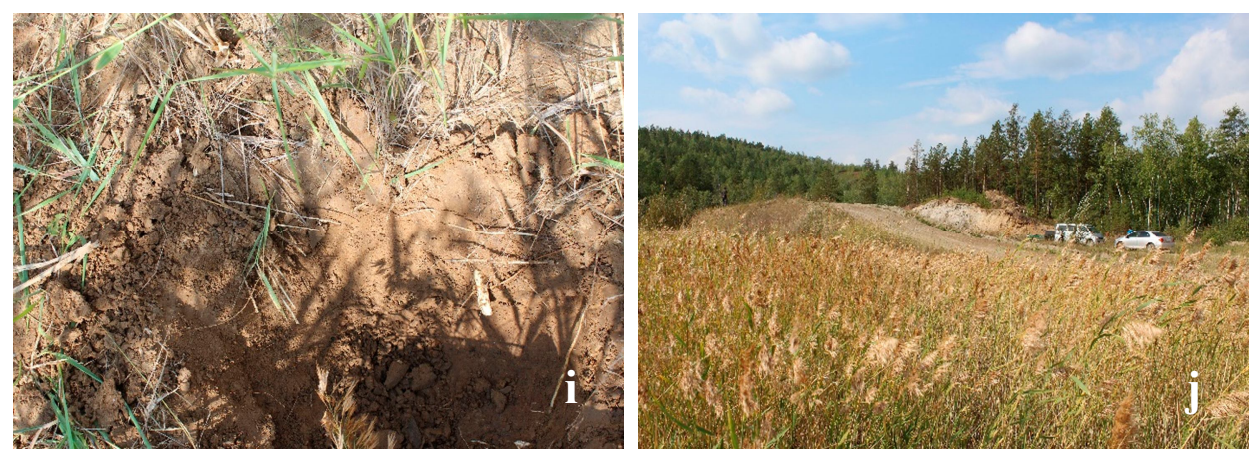

Fig. 1. Sampling sites. a- P1 soil, b- P1 -vegetation cover, c- P2 - soils, d- bottom of the quarry with sparse vegetation cover, e- P3 - soil, f- P3 - spontaneous revegetation, g- Y1 - soil, h- spontaneous revegetation, i- Y2 - soil, j- spontaneous revegetation.

\section{Metagenomic studies. DNA isolation}

DNA was isolated using the MN Nucleo Spin Kit (MN, Germany). A Precellus 24 homogenizer (Bertin, USA) was used as a destructive mechanical action. The quality

\section{DNA Sequencing}

DNA sequencing was performed via Illumina MiSEQ sequencing system (USA), with primers F515 (GTGCCAGCMGCCG CGTAA) and R806 (GGACTACVSGGG

\section{Bioinformatic data processing}

Sequence trimming was performed in the Trimmomatic program (Bolger et al. 2014). Forward and reversed reads were combined using fastq-join software of expression analysis (Aronesty 2013).

VSEARCH open source tool (Rognes et al. 2016) was used to search and filter chimeric sequences. Operational Taxonomic Units (OTUs) were determined using

\section{Real-Time PCR}

For quantitative PCR, we used primers against three groups of microorganisms: bacteria - EUB338 (ACTCCTACGGGAG GCAGCAG) and EUB518 (ATTACCGC of the resulting preparation was checked electrophoretically (1\% agarose gel, BioRad, USA) and by PCR (Bio-Rad T100 Thermal Cycler).

TATCTAAT) for V4 variable region of the 16S rDNA gene (Bates et al. 2011), according to user's manual.

the close reference method based on the SILVA database (Rognes et al. 2016, Yilmaz et al. 2014). OTUs, attributed as chloroplast/mitochondrial were removed. Alpha and beta diversity analyses were also performed using the QIIME package (Caporaso et al., 2010) and the mantel test from the QIIME package, with 999 permutations.

GGCTGCTGG) - Lane (1991), Muyzer et al. (1993); archaea - ARC915f (AGGAAT TGGCGGGGGAGCAC) and ARC1059r (GCCATGCACCWCCTCT) - Yu et al. 
(2005); fungi - ITS1f (TCCGTAGGTGA ACCTGCGG) and 5.8S (CGCTGCGTTC TTCATCG) - Gardes and Bruns (1993). To prepare the reaction mixture, the qPCRmix -HS SYBR Kit (Eurogen, Russia) was used according to the manufacturer's instructions. A series of ten-fold dilutions of

\section{Results and Discussion}

\section{Chemical analysis}

Table 2 provides data for multiple agrochemical parameters. The upper horizon of the Y1 quarry is characterized by a high level of basal respiration (BR), comparatively high fractions of organic carbon and nitrogen in the soil, and neutral $\mathrm{pH}$ values. Such conditions contribute to the growth of microorganisms, which is also reflected in a number of rDNA gene copies, obtained by Real-Time PCR. The lower horizon, however, is relatively poor: small amounts of nitrogen and carbon and a low basal respiration. The Y2 quarry also shows

\section{Alpha biodiversity}

The alpha diversity was described using multiple approaches, including the classical Shannon indices, the number of OTE found, the indices that take into account the phylogenetic diversity of the population (PD Whole Tree), and the estimated number of species (Chao1). The results are shown in Table 3.

Alpha diversity indices were determined by a combination of soil and vegetation. Thus, the PD Whole Tree index, which is a measure of the phylogenetic diversity of populations, is significantly higher in the Y1.AY sample (superficial layer) than in other samples studied. Also, the high value of the Shannon index (as well as the estimated number of species, Chaol) appears to be associated with a large number of bacteria involved in interactions with various plants. The lower layer of the same portion (Y1.C) is substantially poorer.
16S (E. coli and H. pilori) and ITS1 (S. cerevisiae) fragments were used as standards. A CFX96 thermocycler (BioRad, Germany) was used to perform PCR using the cycling parameters: $95^{\circ} \mathrm{C}$ for $3 \mathrm{~min}, 40 \mathrm{cy}-$ cles of $95^{\circ} \mathrm{C}$ for $20 \mathrm{~s}, 50^{\circ} \mathrm{C}$ for $20 \mathrm{~s}, 72^{\circ} \mathrm{C}$ for $20 \mathrm{~s}$.

low levels of BR and nitrogen and carbon levels.

In the P1 quarry, there is a decrease in $\mathrm{pH}$ compared to Y1. Relatively large amounts of carbon and nitrogen were found in the P1. Low levels of nutrition components in P2 and P3 quarries, might be explained by the real-time PCR results (see below). Data obtained are in good agreement with those previously published for initial soils of Yakutia (Danilova et al. 2012, Savvinov 2009, 2014).

The second spot (Y2) does not exhibit such heterogeneity across the layers within the depth. Samples of Y2.AY and Y2.C do not differ in terms of alpha diversity. It is likely that the monoid cane seeding contributes to the formation of a less diverse soil community than occurs with seeding by different plants.

The Namsky quarries (samples P1 to P3) are characterized by generally low levels of alpha diversity, except for samples P1.AO. This, however, is again due to the presence of different vegetation at the bottom of the quarry. Even in this case, the values of the PD Whole Tree, Chaol, and Shannon indices are less than those of the Y1.AY sample and are comparable to the variety of other soils. The diversity indices are consistently low in the $\mathrm{P} 2$ and $\mathrm{P} 3$ samples, as well as in the $\mathrm{P} 3$ sample, which is associated with the young pine forest. 


\begin{tabular}{|c|c|c|c|c|c|c|c|}
\hline & pHH20 & pHKCl & EA & HA & $\begin{array}{c}\text { Carbon, } \\
\text { \% }\end{array}$ & $\begin{array}{c}\text { Nitrogen, } \\
\text { \% }\end{array}$ & $\begin{array}{c}\text { BR CO } \\
\text { mg/g of } \\
\text { soil/hour }\end{array}$ \\
\hline Y1.AY & 5.27 & 4.98 & 0.3 & 0.3 & 0.33173 & 0.03937 & 0.050 \\
\hline Y1.C & 5.87 & 5.23 & 0.1 & 0.2 & 0.03728 & 0.01269 & 0.020 \\
\hline Y2.AY & 5.92 & 5.54 & 0.5 & 0.5 & 0.72785 & 0.05032 & 0.017 \\
\hline Y2.C & 6.02 & 5.76 & 0.2 & 0.2 & 0.5346 & 0.04135 & 0.015 \\
\hline P2 & 5.76 & 5.54 & 0.1 & 0.2 & 0.03366 & 0.01602 & 0.023 \\
\hline P3 & 5.32 & 5.12 & 0.3 & 0.3 & 0.1283 & 0.02718 & 0.027 \\
\hline P1.OA & 4.87 & 4.75 & 0.1 & 0.2 & 1.062 & 0.0715 & 0.016 \\
\hline
\end{tabular}

Table 2. Nutrition parameters (color represent value: from red to green). Note: $\mathrm{pHH} 20-\mathrm{soil} \mathrm{pH}$ in water suspension, $\mathrm{pHKCl}$ - soil $\mathrm{pH}$ in salt suspension, EA - exchangeable acidity, HA - hydrolithical acidity, BR - basal respiration.

\begin{tabular}{|l|l|l|l|l|}
\hline Sample & \multicolumn{1}{|c|}{ PD whole tree } & \multicolumn{1}{|c|}{ Chao1 } & \multicolumn{1}{c|}{ Observed OTUs } & \multicolumn{1}{c|}{ Shannon } \\
\hline P1.AO & $\mathbf{8 7 . 1 3} \pm 6.57$ & $\mathbf{2 4 9 9 . 4 3} \pm 341.51$ & $\mathbf{1 3 1 9 . 3 3} \pm 123.45$ & $\mathbf{9 . 3 3} \pm 0.18$ \\
\hline P1.C & $\mathbf{7 7 . 7 9} \pm 4.74$ & $\mathbf{2 1 9 1 . 5 4} \pm 36.94$ & $\mathbf{1 2 2 2 . 3 3} \pm 63.04$ & $\mathbf{9 . 1 2} \pm 0.12$ \\
\hline P2.C & $\mathbf{5 7 . 3 5} \pm 17.92$ & $\mathbf{1 0 4 3 . 1 1} \pm 417.38$ & $\mathbf{6 6 1 . 3 3} \pm 229.32$ & $\mathbf{6 . 6 7} \pm 1.23$ \\
\hline P3. AO & $\mathbf{5 2 . 3 2} \pm 16.03$ & $\mathbf{1 2 5 3 . 6 9} \pm 468.37$ & $\mathbf{7 2 0 . 6 7} \pm 246.70$ & $\mathbf{7 . 4 7} \pm 1.21$ \\
\hline Y1.AY & $\mathbf{1 0 5 . 5 6} \pm 0.85$ & $\mathbf{2 4 8 2 . 3 6} \pm 48.90$ & $\mathbf{1 3 9 6 . 0 0} \pm 28.93$ & $\mathbf{9 . 5 8} \pm 0.06$ \\
\hline Y1.C & $\mathbf{7 4 . 3 0} \pm 1.22$ & $\mathbf{1 2 0 4 . 9 4} \pm 180.85$ & $\mathbf{8 3 1 . 6 7} \pm 36.67$ & $\mathbf{7 . 8 4} \pm 0.66$ \\
\hline Y2.AY & $\mathbf{8 0 . 6 6} \pm 16.67$ & $\mathbf{1 6 4 6 . 9 8} \pm 539.84$ & $\mathbf{9 6 6 . 3 3} \pm 258.79$ & $\mathbf{8 . 4 9} \pm 0.69$ \\
\hline Y2.C & $\mathbf{9 4 . 1 0} \pm 3.40$ & $\mathbf{2 2 4 2 . 0 2} \pm 103.55$ & $\mathbf{1 1 9 4 . 0 0} \pm 60.40$ & $\mathbf{9 . 0 7} \pm 0.20$ \\
\hline
\end{tabular}

Table 3. Main alpha-diversity indices. Note: PD - phylogenetic distanse, Chaol - explains expected number of OTUs in infinity number of reads, OTU- Operational Taxonomic Unit. Group of reads with really high similarity in sequences (more than $97 \%$ ). The data points are means \pm SD.

\section{Beta diversity}

Fig. $2 \mathrm{~A}$ and B show the results of beta diversity analysis applying the weightedunweighted UniFrac technique (Lozupone and Knight 2007).

Although the horizons of the $\mathrm{AO}$ and $\mathrm{C}$ from P1 pits were similar, forming a homogenous clusters, it seems likely that the morphologically different horizons do not differ microbiologically. The structures of the microbial communities found in pit P3 are similar to those of $\mathrm{P} 1$. The microbial communities of pit P2 differ from other communities of this group, and - according to the weighted and unweighted analyses are mostly similar to the communities of the gentle horizons of pits Y1 (Y1.C). This similarity is likely a result of the poverty of the soil and the presence of only trace quantities of vegetation.

The communities of the Y1 pit soil horizons differ significantly from each other. The communities of the upper horizon are formed by a separate cluster. Such differences are likely a result of the wide variety of plants, presented by lower and vascular plants and, as a result, more active processes of metabolism. In the second pit of the same group (Y2), such changes were not detected. Therefore, the communities of the soil horizons do not differ from each other. The communities of the Y2 pit form an isolated cluster. It might be connected with monospecific overgrowing by reed (Phragmites australis). 


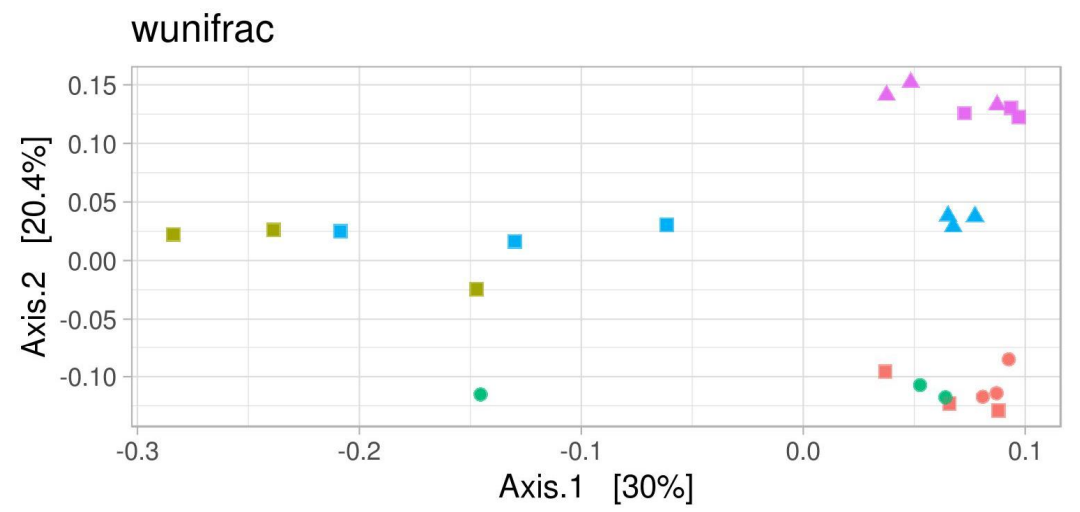

- $\mathrm{A} 0$

- $A Y$

- C

Sample

- P1

- P2

- P3

- Y1

Horizont

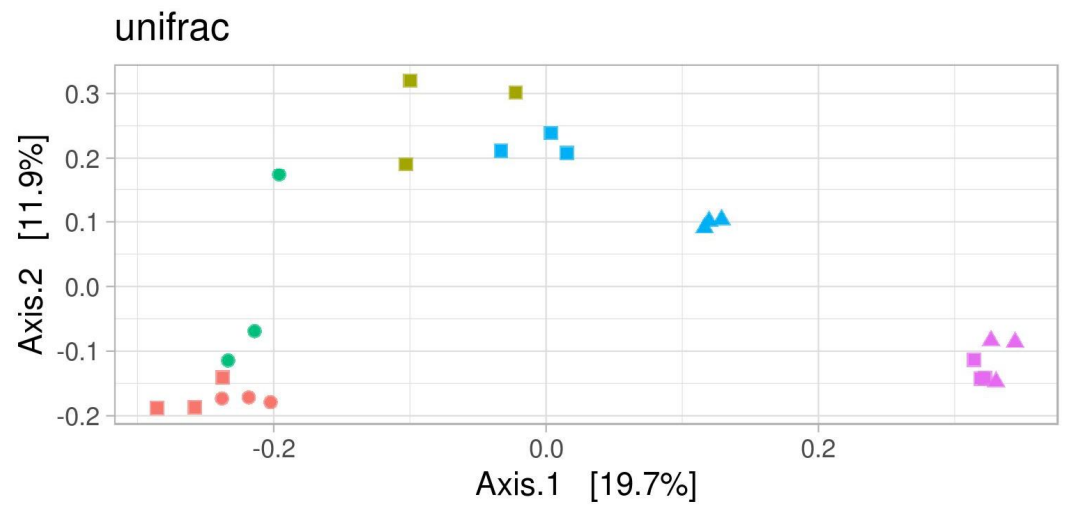

- $\mathrm{A} 0$

- $A Y$

- $\mathrm{C}$

Sample

- P1

- P2

- P3

- $Y_{1}$

- Y2

Fig. 2. Results of Unifrac analyzes. A- PCoA of unweighted UniFrac, B - PCoA of we weighted UniFrac. P1, P2,P3, Y1 - sample codes, A0, AY, C - names of soil horizons.

\section{Taxonomic structure of the soil microbiome}

The taxonomic structure of the communities discussed at the family level is shown in Fig. 3.

Taxonomy compostion of soil microbiome is presented by normal phyla's, typical for polar and boreal environments of Eurasia (Pershina et al. 2018b). The familylevel taxonomic analysis revealed differences among individual points. The quarry of $\mathrm{P} 1$ is characterized by the presence of Alphaproteobacteria (represented mainly by the family Rizobiales) and Gammaproteobacteria, as well as members of Actinobacteria and Acidobacteria in the upper horizon (P1.AO). Alphaproteobacteria con-tinue to dominate the lower horizon (P1.C), together with Actinobacteria and Bacteroidetes (mostly Chitinophagales). The microbial community of $\mathrm{P} 2$ is formed by two dominant taxomonic groups $32 \%$ of the community here is occupied by representatives of Bacilli (Baciliales), and $22 \%$ by Gammaproteobacteria. A significant number of Alphaproteobacteria (17\%) and Actinobacteria (27\%) are also present. The P3 quarry includes a large number of already seen Actinobacteria (23\%), Alphaproteobacteria $(11 \%)$, and multiple Bacteroidetes (up to $8 \%$ ). 


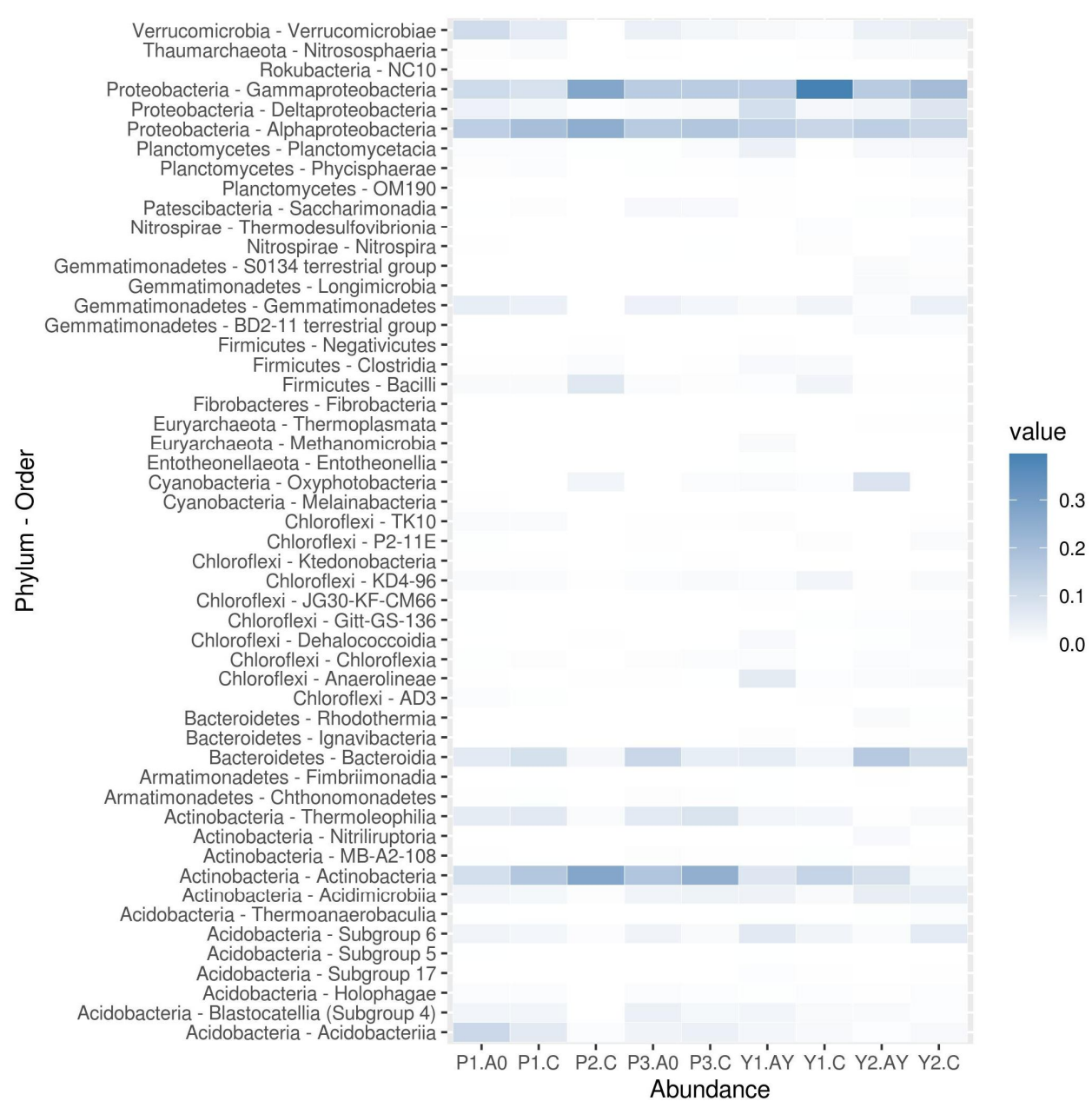

Fig. 3. Main taxa in bacterial communities, family level.

The upper horizon (Y1) represents a wide variety of bacteria. In addition to Alphaproteobacteria and Gammaproteobacteria, Deltaproteobacteria and Chloroflexi were also found. However, the lower horizon is extremely uniform; $38 \%$ of the community belongs to Gammaproteobacteria. The Y2 topsoil horizon is moderately diverse, with a preponderance of $\mathrm{Bac}$ teoidetes. The lower horizon also moder- ately diverse, Gamma-, Alpha-, and Bacteroidetes are well represented. In general, taxonomy diversity is lesser, that in soils of postmining areas of boreal zone, which were revealed for south taiga zone (Dmitrakova et al. 2008a, b). This can be result in different vegetation types and climatic conditions, as it was shown for microbiomes of zonal soil sequences (Pershina et al. 2018b). 


\section{Real-Time PCR}

Fig. 4 shows real-time PCR data for the number of bacteria, archaea, and fungi in the samples. The largest number of bacteria was observed in the upper layer of the Y1 quarry (Y1.AY). There are slightly fewer bacteria in the samples from quarry $\mathrm{P} 1$ (P1.AO and P1.C), and in this quarry, their number is relatively large in both horizons (P1.OA and P1.C). In other horizons, the number of bacteria is stably low. This well corresponds with data of Frouz et al. (2016) and Harantová et al. (2017) who revealed strong dependence of soil microbiome quality and diversity from development rate of soil profile. A similar situ-ation - the prevalence of organisms in the upper layer of the $\mathrm{Y} 1$, and in both horizons of the $\mathrm{P} 1$ - is observed in the analysis of the number of fungi and archaea. Only the number of archaea in the upper horizon of the quarry of Y2 is reliably distinguished: upper layer (Y2.AY) shows more organisms, than in the lower horizon (Y2.C), or the quarry P3. The quantity of arhchaea is quite different in comparison with initial soils of temperate climate, which are more developed and enriched by nutrients (Pershina et al. 2019, Dmitrakova et al. 2018a, b). Thus, the regeneration potential of soil microbiota can be assessed as low for initial soils of central Yakutia.
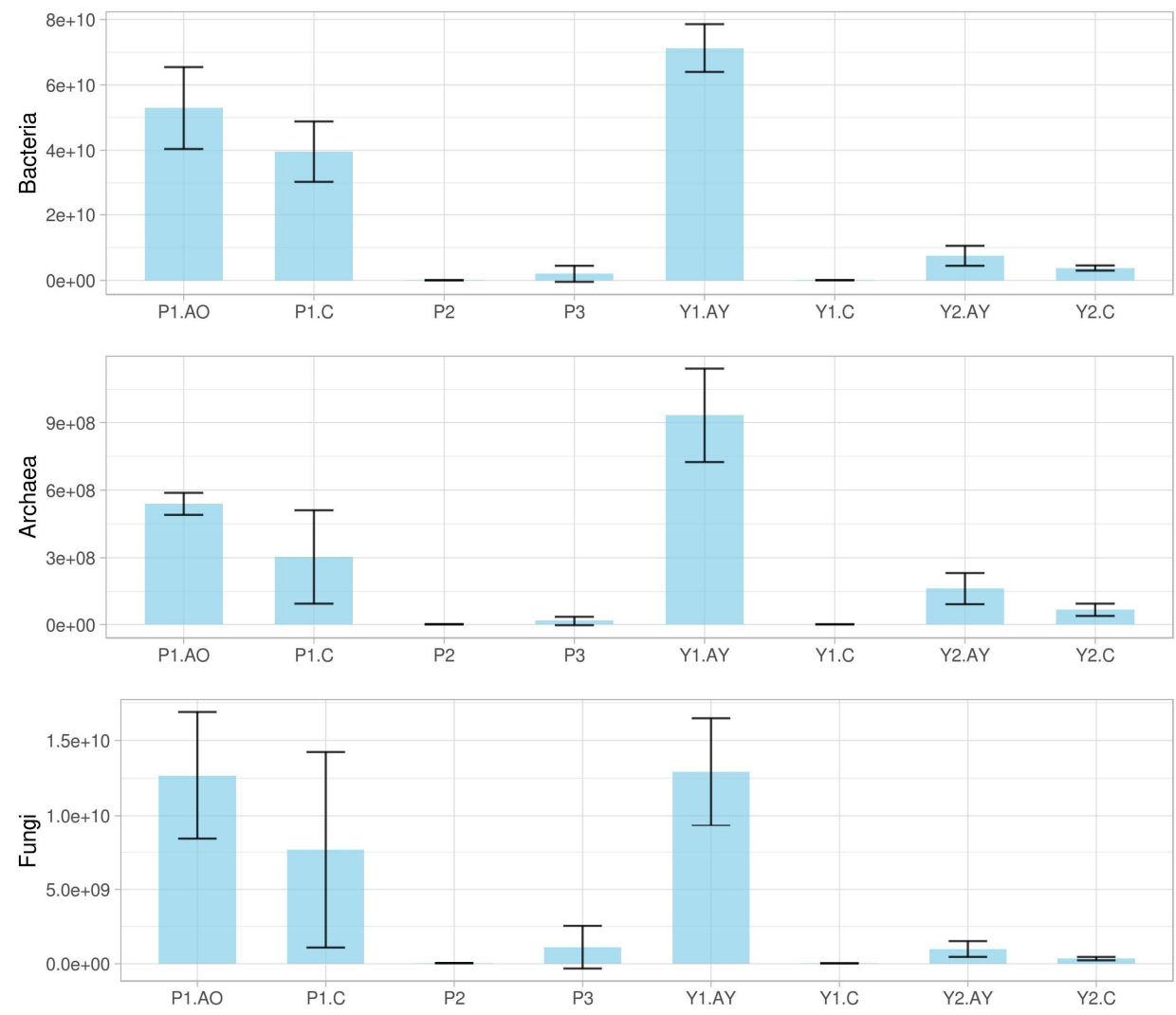

Fig. 4. Quantity of archaea, bacteria and fungi in samples, by Real-Time PCR data. The data points are means $\pm \mathrm{SD}$ (standard deviation). 


\section{Conclusions}

In this study, the initial soils of cryolithozone were characterized by few bacteria, limited microbial biodiversity, and reduced metabolic activity in comparison with initial soil of temperate climate. Because of this, the soil regeneration rate is slow. The variety of sites included in this study allowed us to characterize different processes of soil regeneration at different sites and stages of this process. Among the tested quarries, the P2 quarry exhibited characteristics such as low nitrogen and carbon content, lack of vegetation, and extremely low alpha diversity indexes. Nevertheless, beta diversity and real-time PCR data showed some heterogeneity of quarry samples. This is most likely due to some heterogeneity of the environmental microniches formed in the soil and the slightly different composition of individual topsoil layers and consortium of such ecological niches.

The soil samples collected from the P3 quarry were also relatively poor. Regarding alpha diversity, the number of bacterial OTE was higher than in P2, but phylogenetically the communites are closer. Regarding the beta diversity, samples from this community differed significantly from the other samples, possibly due to soil features and the taxonomic composition of bacteria characteristic of monoid sprouting. However, the amounts of archaea, bacteria, and fungi remained low. The Among the Kildyam quarries, the Kildyam P1 soil had the greatest diversity indices. The upper horizon (P1.AO) exhibited a relatively high (greater than in other quarries of this group) content of microbial carbon and nitrogen (which are indicators of alpha diversity), as well as a substantially greater number of bacteria, fungi, and archaea (by hundreds of times). This diversity is likely facilitated by diverse vegetation, including herbs and trees. In the lower horizon (P1.C), the the indicators reached lower numeric values than in other horizons (the amount of microbial carbon and nitrogen, and the diversity indices, the total number of bacteria, archaea, and fungi). However, these parameters remained larger than in the samples of revegetated sites. This is due to the extremely small thickness of the upper horizon: most of the microbial processes continue in the lower horizon of the soil.

In Y1 quarry, substantial difference was found between the horizons due to higher rate of soil development. The upper horizon of Y1.AY $(0-5 \mathrm{~cm})$ was rich in microbial carbon and nitrogen, as well as diverse. Among the tested samples, the upper horizon of Y1.AY $(0-5 \mathrm{~cm})$ had the most bacteria, fungi, and archaea (PCR data) from the overall list, and the largest alpha-diversity index. The lower horizon was extremely poor: indices of alpha- and beta-diversity were similar to the P2 indices, discussed earlier. The main proportion (38\% of all readings of $16 \mathrm{~S}$ rDNA) was represented by Gammaproteobacteria families. This difference might be due to the presence of diverse, predominantly herbaceous plants (Onagraceae, Poaceae). Their root systems are located in the upper horizon of the quarry. Therefore, exchange of metabolites in the root-soil interface happens in the upper horizon, while the underlying layers remain almost unaffected.

The soil horizons of the Y2 quarry were relatively homogenous, with only minor differences in alpha- and beta-diversity and amounts of organisms detected by realtime PCR. These are moderately active soil communities, with betadiversity scores that differed from most of the other tested soils, possibly due to the features of the original soils and monoid germination.

Metagenomic data obtained for the first time for soils of mining heaps of Eastern Siberia will be usefull in future for elaboration the soil reclamation strategies in severe Arctic conditions with taking into account original information about key microbial drivers of initial soil formation. 
A. ZVEREV et al.

\section{References}

Abakumov, E., Pershina, E., Ivanova, E., Anronov, E. (2017): Prokaryotic communities of natural and antropogenically affected soils of King-George Island, Western Antarctica Proceedings of the VII International Conference on Cryopedology "Cryosols in Perspective: A View from the permafrost Heartlands", Yakutsk-Moscow, pp. 4-5.

Ananeva, N. D., Susyan, E. A., Gavrilenko, E. G. (2011): Peculiarities of determination of microbial biomass carbon by the method of substrate of induced breathing. Soil Science, 11: 1327-1333.

Andronov, E. E., Pinaev, A. G., Pershina, E. V., Chizhevskaya, E. P. (2011): Scientific and methodological recommendations for the isolation of highly purified DNA preparations from environmental objects / Ed. A.A. Belimov. St. Petersburg. 23 p.

Aronesty, E. (2013): Comparison of Sequencing Utility Programs, The Open Bioinformatics Journal, 7: 1-8.

Bates, S. T., Berg-Lyons, D., Caporaso, J. G., Walters, W. A., Knight, R. and Fierer, N. (2011): Examining the global distribution of dominant archaeal populations in soil. ISME Journal, 5(5): 908-917.

Bolger, A. M., LohSE, M., UsAdel, B. (2014): Trimmomatic: A flexible trimmer for Illumina Sequence Data. Bioinformatics, 30(15): 2114-2120.

Caporaso, J. G., Kuczynski, J., Stombaugh, J., Bittinger, K., Bushman, F. D., Costello, E. K., Fierer, N., Peña, A. G., Goodrich, J. K., Gordon, J. I., Huttley, G. A., Kelley, S. T., Knights, D., Koenig, J. E., Ley, R. E., Lozupone, C. A., Mcdonald, D., Muegge, B. D., Pirrung, M., Reeder, J., Sevinsky, J. R., Turnbaugh, P. J., Walters, W. A., Widmann, J., YATSUNENKO, T., ZANEVELD, J., KNIGHT, R. (2010): QIIME allows analysis of high-throughput community sequencing data. NATURE Methods. - doi:10.1038/nmeth.f.303

Danilova, A. A., Savvinov, G. N., Danilov, P. P., Petrov, A. A. (2012): Biological characteristics of the soil of perennial dumps of the diamond mining industry of Yakutia. Siberian Journal of Ecology, 5: 749-756.

Deslippe, J. R., Hartmann, M., Simard, S. W., Mohn, W.W. (2012): Long-term warming alters the composition of arctic soil microbial communities. FEMS Microbiology Ecology, 82(2): 303-315. 10.1111/j.1574-6941.2012.01350.

Dmitrakova, Ya. A., Abakumov, E. V., Pershina, E. A., Ivanova, E. A., Andronov, E. E. (2018a): Dynamics of the plant community and microbiome of chrono-series of posttechnological soil in limestone quarry in the conditions of recultivation. Sel'skokhozyaistvennaya Biologiya, 53(3): 557-569.

Dmitrakova, Y. A., Rodina, O. A., Alekseev, I. I., Polyakov, V. I., Petrova, A. A., Pershina, E. V., Ivanova, E. A., ABAKumov, E. V., KosteCKi, J. (2018b): Restoration of soil-vegetation cover and soil microbial community at the Pechurki limestone quarry (Leningrad region, Russia. Soil Science Annual, 69(4): 272-286.

Frouz, J., Toyota, A., Mudrak, O, Jílkov, V., Filipov, A., CAJThaml, T. (2016): Effects of soil substrate quality, microbial diversity and community composition on the plant community during primary succession. Soil Biology and Biochemistry, 99: 75-84.

GARDES, M., BRUNS, T. D. (1993): ITS primers with enhanced specificity for basidiomycetes Application to the identification of mycorrhizae and rusts. Molecular Ecology, 2: 113-118. doi:10.1111/j.1365-294X.1993.tb00005.X.

Harantová, L., Mudrák, O., Kohout, P., Elhottová, D., Frouz, J., Baldrian, P. (2017): Development of microbial community during primary succession in areas degraded by mining activities. Land Degradation \& Development, 28: 2574-2584. https://doi.org/10.1002/ldr.2817.

KIRTSIDELI, I. Y., VlaSOV, D. Y. (2016): Geographic distribution and biodiversity of microfungi in soils of the Arctic regions (at Taimyr Peninsula and Nearby Islands As a Simulation Model of Arctic). In Terrestrial Biomes: Geographic Distribution, Biodiversity and Environmental Threats. Nova Science Publishers, Inc., pp. 1-16. 
Kirtsideli, I. Y., Vlasov, D. Y., Barantsevich, E. P., Krylenkov, V. A. and Sokolov, V. T. (2014): Microfungi from soil of polar Island Izvestia tsik (Kara Sea). Mikologiya $i$ Fitopatologiya, 48: 365-371.

Kirtsideli, I. Y., Abakumov, E. V., Teshebaev, S. B., Zelenskaya, M. S., Vlasov, D. Yu., Krylenkov, V. A., Ryabusheva, Y. V., Sokolov, V. T. and Barantsevich, E. P. (2016): Microbial communities in regions of arctic settlements. Gigiena i Sanitarija, 95: 923-929.

Kirtsideli, I. Yu., Vlasov, D. Yu., Abakumov, E.V., Barantsevich, E. P., Novozhilov, Y. K., Krylenkov, V. A., Sokolov, V. T. (2017a): Airborne fungi in arctic settlement Tiksi (Russian Arctic, coast of the Laptev Sea). Czech Polar Reports, 2: 300-310.

Kitrsideli, I., Teshebaev, S., Vlasov, D., Novozhilov, Yu., Abakumov, E., Barantsevithc, E., KRYlenkov, V., Zelenskaya, M. (2017b): Changes in microbial communities in primary soil and ground under the antropogenic influence on the territory of Antarctic station Mirniy. Gigena I sanitariya, 10: 949-955.

LANE, D. J. (1991): 16S/23S rRNA Sequencing. In: E. Stackebrandt, M. Goodfellow (eds.): Nucleic acid techniques in bacterial systematic. John Wiley and Sons, New York, pp. 115-175.

Li, Y., Chen, L., Wen, H. (2015): Changes in the composition and diversity of bacterial communities 13 years after soil reclamation of abandoned mine land in eastern China. Ecological Research, 30: 357-366. https://doi.org/10.1007/s11284-014-1230-6

Lozupone, C. A., KNIGHT, R. (2007): Global patterns in bacterial diversity. Proceedings of the National Academy of Sciences of the United States of America, 104(27): 11436-11440.

Muyzer, G., De WaAl, E. C., UitTerlinden, A. G. (1993): Profiling of complex microbial populations by denaturing gradient gel electrophoresis analysis of polymerase chain reactionamplified genes coding for 16S rRNA. Applied and Environmental Microbiology, 59(3): 695700 .

Pershina, E. V., Ivanova, E. A., Abakumov, E. V., Andronov, E. E. (2018a): The impacts of deglaciation and human activity on the taxonomic structure of prokaryotic communities in Antarctic soils on King George Island. Antarctic Science, 30(5): 278-288.

Pershina, E. V., Ivanova, E. A., Korvigo, I. O., Chirak, E. L., Sergaliev, N. H., Abakumov, E. V., Provorov, N. A., ANDronov, E. E. (2018b): Investigation of the core microbiome in main soil types from the East European plain. Science of the Total Environment, 631-632: 14211430.

Pershina, E., Ivanova, E., Karpova, D., Rogova, O., Abakumov, E., Andronov, E. (2019): Soil microbiome in chronosequence of spoil heaps of Kursk Magnetic Anomaly. Biological Communications, 3: 23-30.

Rognes, T., Flouri, T., Nichols, B., Quince, C., MahÉ, F. (2016): VSEARCH: a versatile open source tool for metagenomics. PeerJ 4:e2584. doi: 10.7717/peerj.2584

Savvinov, G. N., Danilova, A. A., Danilov, P. P., Boeskorov, V. S., Petrov, A. A., Alekseev, G. A. (2009): Comprehensive diagnostics of soil in reclaimed dumps in Western Yakutia according to the state of soil invertebrates and microbiotaю. Problems of Regional Ecology, 3: 61-65.

Savvinov, G., Danilova, A., Petrov, A., Danilov, P. (2014): Properties of young soils in dumps of diamond mining in the Western Yakutia. Advances in Environmental Biology, 8: 419-424.

Vlasov, D. Y., Abakumov, E. V., Tomashunas, V. M., Krylenkov, V. A., Zelenskaya, M. S. (2014): Mycobiota of soil and anthropogenic substrates of the Yamal Peninsula. Gigiena $i$ sanitaria, (5): 49-51.

White, R. A., Power, I. M, Dipple, G. M., Southam, G., Suttle, C. A. (2015): Metagenomic analysis reveals that modern microbialites and polar microbial mats have similar taxonomic and functional potential. Frontiers in Microbiology, 966, https://doi.org/10.3389/fmicb.2015.00966

Yilmaz, P., Parfrey, L. W., Yarza, P., Gerken, J., Pruesse, E., Quast, C., Schweer, T., Peplies, J., Ludwig, W., Glöckner, F. O. (2014): The SILVA and "All-species Living Tree Project (LTP)" taxonomic frameworks. Nucleic Acids Research, 42: 643-D648.

Yu, Y., LEE, C., HwANG, S. (2005): Analysis of community structures in anaerobic processes using quantitative real-time PCR method. Water Science and Technology, 52: 85-91, doi:10.2166/ wst.2005.0502. 
A. ZVEREV et al.

\section{Web sources / Other sources}

[1] Research park of Saint-Petersburg State University; https://researchpark.spbu.ru/equipmentanalyt-rus/211-masv-ea3028-rus

[2] GOST 26489-85 Soils. Determination of exchangeable ammonium by CINAO method

[3] GOST 26951-86 Soils. Determination of nitrates by ionometric method

[4] GOST R 54650-2011 Soils. Determination of mobile phosphorus and potassium compounds by Kirsanov method modified by CINAO 